\title{
CLOPYRALID DISSIPATION IN THE SOIL CONTAMINATED WITH HEAVY METALS
}

\author{
Mariusz Kucharski ${ }^{1}$, Olga Kalitowska ${ }^{1}$ \\ 1 Institute of Soil Science and Plant Cultivation - State Research Institute, Department of Weed Science and \\ Tillage Systems, Orzechowa 61, 50-540 Wrocław, Poland, e-mail: m.kucharski@iung.wroclaw.pl; o.kalitow- \\ ska@iung.wroclaw.pl
}

Received: 2014.07.31

Accepted: 2014.10.17

Published: 2015.01.02

\begin{abstract}
The aim of the studies was to determine the influence of copper and zinc contamination on clopyralid dissipation in soil. The experiment was carried out in laboratory conditions (plant growth chamber). Clopyralid was applied to three different soils [similar textures, $\mathrm{pH}$, organic carbon content and contrasting copper and zinc content: soil natural contaminated with $\mathrm{Cu}$ and $\mathrm{Zn}(\mathrm{S} 1)$, soil with natural low $\mathrm{Cu}$ and $\mathrm{Zn}$ concentration (S2) and soil S21 prepared in the laboratory (S2 soil additionally contaminated with $\mathrm{Cu}$ and $\mathrm{Zn}$ salts in the amounts equivalent to contamination level of S1 soil)]. Soil samples were taken for analyses for 1 hour (initial concentration) and 2, 4, 8, 16, 32, 64 and 96 days after treatment. Clopyralid residue was analysed using GC/ ECD (gas chromatography with electron capture detector). Good linearity was found between logarithmic concentration of clopyralid residues and time. The differences in $\mathrm{Cu}$ and $\mathrm{Zn}$ content influenced the clopyralid decay in soil. The values of $\mathrm{DT}_{50}$ obtained in the experiment ranged from 21 to 27 days. A high concentration of $\mathrm{Cu}$ and $\mathrm{Zn}$ in soil slowed down clopyralid degradation (the $\mathrm{DT}_{50}$ value was higher - 25-27 days).
\end{abstract}

Keywords: heavy metals, $\mathrm{Cu}, \mathrm{Zn}$, herbicide, soil, dissipation rate, clopyralid.

\section{INTRODUCTION}

"Głogów II" Copper Smelter and Refinery, a branch of KGHM Polska Miedź S.A., is the source of soils contamination with heavy metals, especially with copper and zinc. In this region, high content of these metals in the soils also results from the type of bedrock [Jaworska, Dąbkowska-Naskręt 2012]. Direct neighborhood of the copper smelter and arable land effects on the structure of their use. A common way of the development of this land is cultivation of industrial plants [Kabała et al. 2010]. High content of copper and zinc influences a number of soil biological and chemical properties, which can modify the behavior of organisms and substances which are already present in the soil or the ones introduced to it [Valery, Eugene 1998, Nwuche, Ugoji 2008]. The latter possibility can be exemplified by herbicides, which, as one of the basic components of modern technology of plant cultivation, are an alien element introduced to the environment. After fulfilling their weed control function in crops, herbicides should undergo degradation to simple substances, not toxic to the environment. Decomposition of herbicide active substances in the soil dependent on many factors, such as temperature and soil moisture, the type of soil, the content of organic carbon and clay fraction, as the dominant ones [Sedeghi et al. 2000, Li et al. 2003, Rodriguez-Liebana et al. 2013]. Metals like copper or zinc can effect the process of herbicide degradation, which can take place through catalyzed degradation reaction, forming complexes with active substances, which can modify the processes of sorption, transport in the soil and susceptibility to decomposition [Guo et al. 2009]. The process of affecting herbicides by metals can be of an indirect character, through the influence on soil microorganisms, e.g. on their population and activity, and therefore, affect the rate of herbicide decay [Wang et al. 2007, Xu et al.2008]. 
Clopyralid, 3,6-dichloro-2-pyridinecarboxylic acid, selected to the tests, is a phenoxy acid herbicide, which was first developed and produced by U.S. Dow AgroSciences Ltd, and was registered for many annual and perennial broadleaf weeds control in different crops. It is absorbed by the leaves and roots of weed and moves rapidly through the plant, and affects plant cell respiration and growth. This herbicide is generally active in the soil and maybe persistent in soils under anaerobic conditions and with low microorganism [Corredor et al. 2006, Zhao et al. 2011].

The aim of the work was the assessment of the effect of copper and zinc contamination on clopyralid degradation in the soil.

\section{MATERIALS AND METHODS}

\section{Laboratory studies}

The research involved controlled experiments. The soil samples were collected from cultivated fields, from $0-15 \mathrm{~cm}$ arable layer. Two types of soil, featuring naturally diversified content of copper and zinc, were used in the investigation. One of the soils (S1), of increased copper and zinc content, came from the field situated in the vicinity of "Głogów II" Copper Smelter, while the second sample (S2), characterized by low content of $\mathrm{Cu}$ and $\mathrm{Zn}$, was collected from a field near Wrocław. In order to eliminate the effect of the soil properties on herbicide degradation, the soil S2 was selected so that its basic parameters $\left(\mathrm{C}_{\text {org }}\right.$, granulometric composition and $\mathrm{pH}$ ) were similar to the properties of S1 soil. The studies also included additional soil S21 prepared in the laboratory (S2 soil additionally contaminated with $\mathrm{Cu}$ and $\mathrm{Zn}$ salts in the amounts equivalent to contamination level of $\mathrm{S} 1$ soil). The analysis of basic physical and chemical parameters of the soils, as well as the content of heavy metals was done in accredited chemical and agricultural laboratory. The basic parameters of the soils were shown in Table 1.

After sieving the soil through a 2-mm sieve, it was stored in covered trays in a greenhouse for 10 days and regularly mixed. Five days before the experiment was established, S21 soil was prepared by adding $\mathrm{Cu}$ and $\mathrm{Zn}$ salts to $\mathrm{S} 2$ soil in the amounts corresponding to the level of S1 soil contamination. Soil moisture was measured before the start of the trials by heating to dryness for $24 \mathrm{~h}$ at $105^{\circ} \mathrm{C}$ and determining the difference in weight. Soil moisture was set at $60 \%$ of field capacity, checked at regular intervals and adjusted with distilled water to the initial level.

Soil samples were transferred into $90 \mathrm{~mm}$ diameter and $85 \mathrm{~mm}$ height pots that were placed in growth chambers; each variant had four replicates. Day/night temperature regimes were 20/10 ${ }^{\circ} \mathrm{C}$ (average temperatures recorded at the end of April and May - typical term of clopyralid application on the field in Poland) and light intensity was $320 \pm 10 \mu \mathrm{mol} \cdot \mathrm{m}^{-2} \cdot \mathrm{s}^{-1}$ photosynthetic photon flux, with $15 \mathrm{~h}$ day length. Two days after placing the pots into the growth chambers, the commercial formulation of clopyralid (herbicide Lontrel 300 SL; Dow AgroSciences ${ }^{\circledR}$, USA) at a dose 90g of active substance per hectare was applied. Application of herbicide was done using a stationary chamber sprayer equipped with a mobile nozzle TeeJet XR 11003-VS. The nozzle was operated at pressure of $200 \mathrm{kPa}$ and speed $3.6 \mathrm{~km} \cdot \mathrm{h}^{-1}$ producing a spray volume of $250 \mathrm{l} \cdot \mathrm{ha}^{-1}$. Herbicide doses and spraying conditions were the same as for field conditions. Soil samples (one pot containing ca. $250 \mathrm{~g}$ of soil $=$ one sample and one replica) were taken for analysis one hour after herbicide application and 2, 4, 8, 16, 32, 64 and 96 days after treatment. The samples taken from the experiment were well mixed and stored in polyethylene bags at minus $20^{\circ} \mathrm{C}$ until sample extraction.

\section{Clopyralid determination - analytical method}

The analytical procedure consisted of three crucial steps:

1) Extraction of the analyzed substance from the matrix.

Soil samples were homogenized. Soil portions $(3 \times 10 \mathrm{~g})$ were mixed with $3 \times 2.5 \mathrm{~g}$ of Diatomaceous Earth (Dionex ${ }^{\circledR}$ ASE $^{\circledR}$ Prep DE) and

Table 1. Soil characteristics

\begin{tabular}{|c|c|c|c|c|c|c|c|}
\hline Soil & $\begin{array}{c}\mathrm{pH} \\
(1 \mathrm{n} \mathrm{KCl})\end{array}$ & $\begin{array}{l}\mathrm{C}_{\text {org }} \\
{[\%]}\end{array}$ & $\begin{array}{c}\text { Sand } \\
{[\%]}\end{array}$ & $\begin{array}{l}\text { Silt } \\
{[\%]}\end{array}$ & $\begin{array}{l}\text { Clay } \\
{[\%]}\end{array}$ & $\begin{array}{c}\mathrm{Cu} \\
{\left[\mathrm{mg} \cdot \mathrm{kg}^{-1}\right]}\end{array}$ & $\begin{array}{c}\mathrm{Zn} \\
{\left[\mathrm{mg} \cdot \mathrm{kg}^{-1}\right]}\end{array}$ \\
\hline $\mathrm{S} 1$ & 6.4 & 2.21 & 15 & 25 & 60 & 278.2 & 93.6 \\
\hline S2 & 6.2 & 2.09 & 19 & 24 & 57 & 6.8 & 3.6 \\
\hline S21 & 6.5 & 2.09 & 19 & 24 & 57 & 275.9 & 94.2 \\
\hline
\end{tabular}


transferred into stainless steel cells. Extraction was done using accelerated solvent extraction on fully automated Dionex ASE 350 extractor $\left(\right.$ Dionex $^{\circledR}$, CA, USA) [extraction solvent - acetone $(33 \mathrm{~mL}$ per cell for two cycles of extraction), temp. $40{ }^{\circ} \mathrm{C}$, extraction time -20 min. and pressure $-0.2 \mathrm{MPa}$ )]. The combined extracts (from three cells) were then slowly evaporated under a nitrogen stream until dry.

2) Extract cleaning.

Dry residues were dissolved in $10 \mathrm{~mL}$ of water (acidified to $\mathrm{pH}=2$ ) and subjected to SPE (Solid Phase Extraction). $3 \mathrm{~mL}$-capacity cartridges and sorbent bed $-0.5 \mathrm{~g}$ of octadecyl, $40 \mu \mathrm{m}$ particle size $\left(\right.$ Bakerbond $^{\circledR}$, ${ }^{\text {J.T.Baker }}{ }^{\circledR}$, Philipsburg, NJ, USA) were used. The sorbent was preconditioned with water $(3 \mathrm{~mL})$ and then methanol $(3 \mathrm{~mL}) .10 \mathrm{~mL}$ of extract solution was loaded with small portions onto the cartridge and the eluate was discarded. Analytes were eluted with two portions of methanol $(2 \times 1 \mathrm{~mL})$. To eluate was added $20 \mathrm{~mL}$ of water, moved to separator and extracted with two portions of dichloromethane $(2 \times 10 \mathrm{~mL})$. Collected extract was evaporated to dryness. Next, dry residue was dissolved in methanol $(2 \mathrm{~mL})$ and esterified with diazomethane (injection solvent).

3) Final determination.

A gas chromatograph Varian CP 3800 equipped with software Varian GCMS 2000 and the electron capture detector (Varian $\left.{ }^{\circledR}, \mathrm{CA}, \mathrm{USA}\right)$ was used to carry out the final determination. Throughout the entire experiment, a VF-5ms capillary column $(30 \mathrm{~m} \times 0.25 \mathrm{~mm} \times 0.25 \mu \mathrm{m}$ film thickness) ( $\operatorname{Varian}^{\circledR}$, CA, USA) was used. Nitrogen was used as carrier gas at a flow rate of $1.5 \mathrm{~mL} / \mathrm{min}$. Chromatographic separation was performed at the column oven where the initial temperature was held at $120{ }^{\circ} \mathrm{C}$ for 7 $\min$. Then, the temperature ramped at a rate of $10{ }^{\circ} \mathrm{C} / \mathrm{min}$. to $200^{\circ} \mathrm{C}$ and was held for $2 \mathrm{~min}$ utes. Finally, the second ramp was continued at $5{ }^{\circ} \mathrm{C} / \mathrm{min}$. to $230^{\circ} \mathrm{C}$, which was held for 20 $\mathrm{min}$. Injector and detector temperatures were set at 230 and $300{ }^{\circ} \mathrm{C}$, respectively. Aliquots of $1 \mu 1$ of the samples were injected.

The recovery of clopyralid from soil was determined by analyzing fortified samples. The analyses were carried out at four concentration levels in three replicates. The average recovery for all concentration were $97.2 \%$. The quantification limit of the method was $0.0010 \mathrm{mg} \mathrm{kg}^{-1}$.
Each soil sample was analyzed three times. Repeatability of the analytical results was satisfactory, with relative standard deviation (RSD) not exceeding $8.9 \%$ of the mean values. All experimental data was calculated using the statistical program Statgraphics Centurion, version XV and Excel (MS Office 2010).

\section{RESULTS AND DISCUSSION}

The detailed course of clopyralid degradation in the soils was show in Figure 1. The initial clopyralid concentration (analysed 1 hour after application) amounted for all samples to 0.283 $\pm 0.0203 \mathrm{mg} \cdot \mathrm{kg}^{-1}$. The process differed according to the content of copper and zinc in the soil. The slowest rate of clopyralid dissipation was observed in S21 soil (additionally contaminated by the two examined metals). Clopyralid proved to decompose only a bit faster in S1 soil (of high natural $\mathrm{Cu}$ and $\mathrm{Zn}$ content). Significantly faster degradation was recorded in the case of the soil characterized by low $\mathrm{Cu}$ and $\mathrm{Zn}$ content (S2). The differences in clopyralid degradation were maintained in the course of research. Only 96 days after introduction of the herbicide, clopyralid the concentration in all the soils was similar and it ranged, respectively: $3.8 \%$ of initial concentration - S1 soil, $6.2 \%$ - S21 soil and $2.6 \%-\mathrm{S} 2$ soil.

The correlation observed in the research, i.e. slowing of herbicide active substance degradation in the soil contaminated with heavy metals, was confirmed in the research by other authors [Said, Lewis 1991, Pieuchot et al. 1996, Suhadolc et al. 2004, Dictor et al. 2008, Wróbel, Sadowski 2012].

As it was already mentioned in the introduction, clopyralid dissipation takes place mainly in a biological way (soil microorganisms). Numerous investigations prove that higher concentration of metals in the soil does significantly reduce the activity of soil microorganisms, which can slow herbicide degradation [Giller et al. 1998]. In similar research by the authors (not yet published), it was possible to state that the presence of copper and zinc in the soil accelerates metazachlor decomposition, which follows mainly the chemical way.

Diversified chemical structure and metabolic processes of herbicides do not allow to assess the effect of heavy metals on decomposition of these compounds. Similar research should be conducted for particular active substances. 


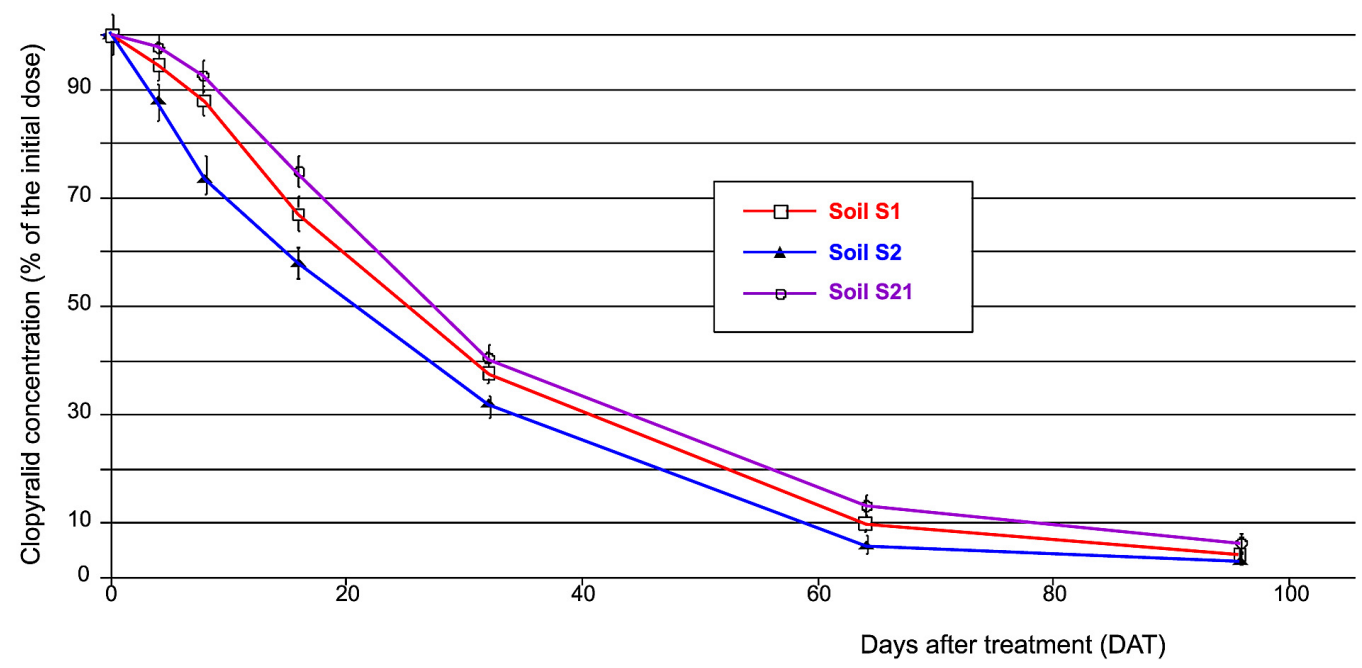

Figure 1. Degradation of clopyralid in soils. Vertical bars represent \pm standard errors of means $(n=3)$

The degradation data was plotted. Good linearity was found between logarithmic concentration of clopyralid residues and time, indicating first-order rates of degradation with correlation coefficients $\left(\mathrm{R}^{2}\right)$ about 0.99 for soils. The $\mathrm{DT}_{50}$ values (graphically derived by interpolating the values between successive residue measurements) varied from 21.1 days for S2 soil, to 27.6 days for $\mathrm{S} 21$ soil. The $\mathrm{DT}_{50}$ values obtained after fitting the curves to first-order kinetics were similar (19.5 and 25.3 days, respectively) (Table 2). The same model of kinetics equation was noticed for clopyralid and other herbicides (Allen, Walker 1987, Ravelli et al. 1997, Ma et al. 2004, Cuevas et al. 2007, Hu et al. 2011, Kucharski, Sadowski 2011, Zhao et al. 2011).

Significant differences in degradation rate of the herbicide in soil in the first period after treatment influenced the $\mathrm{DT}_{50}$ indicator. The $\mathrm{DT}_{50}$ values for soils in this experiment are consistent with the data presented by Smith and Aubin [1998], who measured the dissipation of clopyralid in three prairie soils (clay, clay loam and sandy loam) at different temperatures. They found that dissipation increased as increased temperature (from 10 to 30 ${ }^{\circ} \mathrm{C}$ ), and showed first-order kinetics. Half-lives ranged from 10 to 47 days, and were similar in the clay and sandy loam soils, and greatest in the clay loam soil at higher temperatures.

Different half-life period of clopyralid is significant, but the obtained results do not exceed the range of values published by European Food Safety Authority (EFSA). On the basis of the research results it is possible to state that clopyralid belongs to substances of medium stability in the soil. Its half-life, obtained due to laboratory tests, ranged from 13 to 65 days, while in field experiments it was shorter and amounted to 2-24 days [EFSA Sci. Rep. 2005].

\section{CONCLUSIONS}

1. Clopyralid belongs to the group of moderate persistent compounds, its half-life $\left(\mathrm{DT}_{50}\right)$ in the soil, in this research, ranged from 21 to 27 days.

2. Graphical representation of clopyralid degradation in the soil course takes the form of exponential curve (rate equation of first-order kinetics).

3. The increase in copper and zinc content in the soil influenced clopyralid degradation and $\mathrm{DT}_{50}$ value. Slower degradation, and therefore higher $\mathrm{DT}_{50}$ value was observed in the soil with higher $\mathrm{Cu}$ and $\mathrm{Zn}$ content $\left(\mathrm{DT}_{50}=25-27\right.$ days).

Table 2. Equations for clopyralid degradation curves and values of $\mathrm{DT}_{50}$

\begin{tabular}{|c|c|c|c|}
\hline \multirow{2}{*}{ Object } & \multirow{2}{*}{$\begin{array}{c}\text { Equation of degradation curve } \\
\text { (for average values) }\end{array}$} & Graphically determined & Calculated from equation \\
\cline { 3 - 4 } & $\mathrm{C}_{\mathrm{t}}=0.299 \cdot \mathrm{e}^{-0.0292 \mathrm{t}}, \mathrm{R}^{2}=0.9959$ & $25.32 \pm 2.12$ & 23.73 \\
\hline Soil S1 & $\mathrm{C}_{\mathrm{t}}=0.291 \cdot \mathrm{e}^{-0.0356 \mathrm{t}}, \mathrm{R}^{2}=0.9901$ & $21.13 \pm 1.76$ & 19.47 \\
\hline Soil S2 & $\mathrm{C}_{\mathrm{t}}=0.293 \cdot \mathrm{e}^{-0.0274 \mathrm{t}}, \mathrm{R}^{2}=0.9918$ & $27.64 \pm 2.31$ & 25.29 \\
\hline Soil S21 &
\end{tabular}

Explanation: $\mathrm{C}_{\mathrm{t}}-$ acetochlor concentration at time , $\mathrm{t}$ ”, $\mathrm{R}^{2}-$ correlation coefficient. 


\section{Acknowledgements}

The work has been prepared as a part of 2.6 activity in the Institute of Soil Science and Plant Cultivation - State Research Institute Long-term Program (funded by the Polish Ministry of Agriculture and Rural Development).

\section{REFERENCES}

1. Allen R., Walker A. 1987. Influence of soil properties on the degradation rates of metamitron, metazachlor and metribuzin in soil. Pestic. Sci., 18, 95-111.

2. Corredor M.C., Rodriguez-Mellado J.M., RuizMontoya M. 2006. EC(EE) process in the reduction of the herbicide clopyralid on mercury electrodes. Electrochim Acta, 51, 4302-4308.

3. Cuevas M.V., Cox L., Calderon M.J., Hermosin M.C., Fernandez J.E. 2007. Chloridazon and lenacil dissipation in a clayey soil of the Guadalquivir river marshes (southwest Spain). Agric. Ecos. Environ., 124(3-4), 245-251.

4. Dictor M., Baran N., Gautier A., Mouvet C. 2008. Acetochlor mineralization and fate of its two major metabolites in two soils under laboratory conditions. Chemosphere, 71, 663-670.

5. EFSA Scientific Report. 2005. Conclusion on the peer review of clopyralid, 50, 1-65.

6. Giller K.E., Witter E., McGrath S.P. 1998. Toxicity of heavy metals to microorganism and microbial processes in agricultural soils: A review. Soil Biol. Biochem., 30, 1389-2359.

7. Guo B.Y., Wei W.L., Lin J.M. 2009. The study of the interactions between heavy metals with sulfonylurea herbicides using ACE. J. Chromatographic Sci., 47, 116-120.

8. Hu J.Y., Zhen Z.H., Deng Z.B. 2011. Simultaneous determination of acetochlor and propisochlor residues in corn and soil by solid phase extraction and gas chromatography with electron capture detection. Bull. Environ. Contam, Toxicol., 86, 95-100.

9. Jaworska H., Dąbkowska-Naskręt D. 2012. Influence of Głogów Copper Works on the content of mobile forms of copper and zinc in arable soils. J. Elem., 17, 57-66.

10. Kabała C., Karczewska A., Kozak M. 2010. Przydatność roślin energetycznych do zagospodarowania gleb zdegradowanych. Zesz. Nauk. UP Wroc., Rol., XCVI, 576, 97-118 [In Polish].

11. Kucharski M., Sadowski J. 2011. Behaviour of metazachlor applied with additives in soil - laboratory and field studies. J. Food Agric. Environ., 9(3\&4), 723-726.

12. Li H., Sheng G., Teppen B.J., Johnston C.T., Boyd S.A. 2003. Sorption and desorption of pesticides by clay minerals humic acid-clay complexes. Soil. Sci. Soc. Am. J., 67, 122-131.
13. Ma Q.L., Rahman A., James T.K., Holland P.T., McNaughton D.E., Rojas K.W., Ahuja L.R. 2004. Modeling the fate of acetochlor and terbuthylazine in the field using the Root Zone Water Quality Model. Soil Sci. Soc. Am. J., 68, 1491-1500.

14. Nwuche C.O., Ugoji E.O. 2008. Effects of heavy metal pollution on the soil microbial activity. Int. J. Environ. Sci. Tech., 5, 409-414.

15. Pieuchot M., Perrin-Ganier C., Portal J.M., Schiavon M. 1996. Study on the mineralization and degradation of isoproturon in three soils. Chemosphere, 33, 467-478.

16. Ravelli A., Pantani O., Calamai L., Fust P. 1997. Rates of chlorsulfuron degradation in three Brazilian oxisoils. Weed Res., 37, 51-59.

17. Rodriguez- Liebana J.A., Mingorance M.D., Pena A. 2013. Pesticide sorption on two contrasting mining soils by addition of organic wastes: Effect of organic matter composition and soil solution properties. Colloids and Surfaces A: Physicochem. Eng. Aspects, 435, 71-77.

18. Said W.A., Lewis D.L. 1991. Quantitative assessment of the effects of metals on microbial degradation of organic chemicals. Appl. Environ. Microbiol., 57, 1498-1503.

19. Sadeghi A.M., Isensee A.R., Shirmohammadi A. 2000. Influence of soil texture and tillage on herbicide transport. Chemosphere, 41, 1327-1332.

20. Smith A.E., Aubin A.J. 1989. Persistence studies with the herbicide clopyralid in prairie soils at different temperatures. Bull. Environ. Contam. Toxicol., 42, 670-675.

21. Suhadolc M., Schroll R., Gattinger A., Schloter M., Munch J.C., Lestan D. 2004. Effects of modified $\mathrm{Pb}-, \mathrm{Zn}$-, and $\mathrm{Cd}$ - availability on the microbial communities and on the degradation of isoproturon in a heavy metal contaminated soil. Soil Biol. Biochem., 36, 1943-1954.

22. Valery B., Eugene K. 1998. Soil surface geochemical anomaly around the copper-nickel metallurgical smelter. Water Air Soil Pollut., 103, 197-218.

23. Wang Y.P., Shi J.Y., Wang H., Lin Q., Chen X.C., Chen Y.X. 2007. The influence of soil heavy metals pollution on soil microbial biomass, enzyme activity, and community composition near a copper smelter. Ecotoxicol. Environ. Saf., 67, 75-81.

24. Wróbel S., Sadowski J. 2012. Interaction of copper and herbicide in contaminated soil under remediation. Fres. Environ. Bull., 21, 599-603.

25. Xu J., Yang M., Dai J., Cao H., Pan C., Qiu X., $\mathrm{Xu}$ M. 2008. Degradation of acetochlor by four microbial communities. Bioresource Technol., 99, 7797-7802.

26. Zhao P., Wang L., Chen L., Pan C. 2011. Residue dynamics of clopyralid and picloram in rape plant rapeseed and field soil. Bull. Environ. Contam. Toxicol., 86, 78-82. 